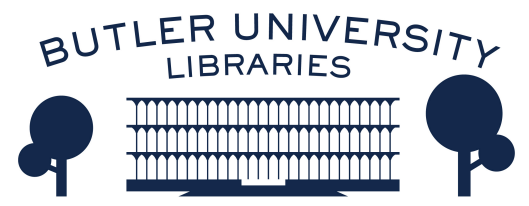

Journal of Hindu-Christian Studies

Volume 20

Article 14

January 2007

\title{
2003-2005 Book Award
}

Corinne Dempsey

Anne Monius

Follow this and additional works at: https://digitalcommons.butler.edu/jhcs

Part of the Religion Commons

\section{Recommended Citation}

Dempsey, Corinne and Monius, Anne (2007) "2003-2005 Book Award," Journal of Hindu-Christian Studies: Vol. 20, Article 14.

Available at: https://doi.org/10.7825/2164-6279.1389

The Journal of Hindu-Christian Studies is a publication of the Society for Hindu-Christian Studies. The digital version is made available by Digital Commons @ Butler University. For questions about the Journal or the Society, please contact cbauman@butler.edu. For more information about Digital Commons @ Butler University, please contact digitalscholarship@butler.edu. 


\section{3-2005 BOOK AWARD}

AT the 2006 meeting for the Society for HinduChristian Studies, held at the American Academy of Religion Convention in Washington D.C., we celebrated our book prize winner, Eliza Kent's Converting Women: Gender and Protestant Christianity in Colonial South India (Oxford University Press, 2004), selected among works published during the years 2003, 2004, and 2005. According to tradition, we honored our prize winner with panel presentations by scholars whose individual research meshes with various aspects of the book, a response by the author, and a discussion. The SHCS book prize tradition began in 1994 with Diana Eck's Encountering God: A Spiritual Journey from Bozeman to Banaras (Beacon Press: 1993) that won recognition among books published during the years 1990-1993. Subsequent book-prize winners have been Francis X. Clooney's Seeing through Texts: Doing Theology among the Srivaisnavas of South India (SUNY: 1996), Julius Lipner's Brahmobandhab Upadhyay: The Life and Thought of a Revolutionary (Oxford University Press, 1999), and Corinne Dempsey's Kerala Christian Sainthood: Collisions of Culture and Worldview in South India (Oxford University Press, 2001).

In order for a book to be considered for the SHCS prize, it must be a distinguished scholarly works that contributes to the field of HinduChristian studies in at least one among a variety of ways. It must involve a comparative study of a theme(s) in Hindu and Christian traditions or of two (or more) thinkers from those traditions; it must trace some aspect of the cultural, historical, political, social, or theological interaction between Hindus and Christians (e.g., in early South Asian history, in the colonial period, in a contemporary setting, in a missionary context, in the diaspora, etc.); and/or it must be a work by an author who belongs (religiously and/or culturally) to either the Hindu or the Christian tradition and reflexively undertakes a study of a concept, image, ritual, author, text, etc., from the other tradition, thus bringing it into dialogue with his or her own.

Over the years, book prize committees have found the pool of books fitting the above criteria increasing in number and quality, making the selection process more difficult yet, happily, reflecting the growing health of the field of Hindu-Christian studies. We include, below, a tribute to our book prize winner, Converting Women: Gender and Protestant Christianity in Colonial South India. Since the Journal previously published a review of Kent's book (see review by Leslie Orr in volume 18, 2005), Anne Monius offers a recap of last year's panel session in further celebration of this cycle's winner.

Corinne Dempsey

University of Wisconsin - Stevens Point

At the 2006 annual meeting of the Society for Hindu-Christian Studies in November, a panel was held honoring the winner of the Best Book in Hindu-Christian Studies Prize, 2003-2005: Eliza F. Kent's Converting Women: Gender and Protestant Christianity in Colonial South India (Oxford University Press, 2004). Panelists included Deepak Sarma (chair), Rita Adluri, Francis Clooney, Rachel McDermott, and Leslie Orr, with responses from the author.

Converting Women is a meticulously researched study of the Protestant mission field in colonial, Tamil-speaking South India, focusing in particular on both Euro-American women missionaries and the Tamil women who converted to Christianity. As outlined in Leslie Orr's review of the book that appeared in an earlier issue of this journal (18 [2005]:64-66), Kent draws creatively on a wide range of historical sources-colonial and missionary archives, writings by and about women missionaries and their converts - to argue for a more nuanced understanding of conversion as a dialogic process, one in which interior experience and exterior social aspiration combined to generate complex webs of personal, 
familial, and social change. Chapter One provides general background information on the Protestant presence in South India, attending carefully to the ways in which developments in Euro-American Christianity influenced the theologies, practices, and goals of missionaries sent to India. Chapter Two examines in detail the worlds of low-caste groups who converted, paying particular attention to the Shanar caste (later renamed Nadars), a community whose traditional (and lowly, in hierarchical terms) occupation of toddy-tapping led many to see the conversion process as a means of upward mobility. Chapter Three provides necessary background information on women's missionary societies in Europe and the United States. The second half of Kent's work turns to the converts themselves and explores what Kent terms the discourse of "respectability" that emerged as an important status marker among Christian converts, with particular focus on the cultivation of feminine modesty and domestic confinement. Chapter Four examines new forms of Indian Christian domesticity and notions of motherhood, while the following chapter underscores the role of companionate marriage in defining low-caste Christian life as respectable and "modern." Chapter Six examines the "Breast-Cloth Controversy" of 1859 and other efforts by convert groups to claim higher status through adopting, more modest clothing styles, particularly for women. Throughout, Kent is careful to demonstrate the diverse interpretations of new symbols and practices; while the adoption of the breast cloth for Shanar/Nadar women, for example, signaled to Euro-American missionaries key feminine virtues of modesty and chastity, for Shanar/Nadar communities themselves, such changes in clothing implied upward mobility through imitation of upper-caste sartorial practice.
In the November panel devoted to Kent's work, a number of interesting themes and questions emerged from the panelists and Kent's responses, a clear measure of the richness of the text and the historical avenues of inquiry it opens up for future research. All praised Kent's ability to eke out with great care and creativity from sparse historical resources that most elusive of subaltern subjects: the low-caste or untouchable woman. Indeed, Kent's reading practices throughout are something of a model for other scholars seeking to "read between the lines" for the voices of non-literate and underrepresented communities and individuals in premodern and early modern South Asia. A cluster of comments and questions also emerged surrounding possible parallels between the processes of identity formation and reformulation for Christian converts that Kent describes and other such processes in South India and elsewhere on the subcontinent. While Kent's work sees clear resonances, for example, between conversion to Christianity and Sanskritization as overlapping efforts at upward mobility through adoption of practices viewed as more upper-caste or more "modern," one wonders how other colonial-era reform efforts fit this pattern, from the neo-Saivas of South India and Sri Lanka to the Hindu Renaissance thinkers of Bengal. In terms of avenues for upward mobility among lower caste groups in history, a number of panelists also pondered the ways in which earlier devotional movements and tantric communities might have provided much the same opportunity as conversion to Christianity.

Anne Monius

Harvard University 